\title{
Ophiolites in the Japanese islands: Typical segment of the circum-Pacific multiple ophiolite belts
}

Japanese ophiolites range from early Paleozo. ic to Cenozoic in age, and their residual peridotite ranges from fertile lherzolite to strongly depleted. calcic clinopyroxene-free harzburgite. They occur as nappes and melanges in a nappe pile that is made up mainly of forearc and deep-sea sediments that have been accumulating in the subduction zones since late Paleozoic time. Otder ophiolites occupy upper structural positions in the nappe pile. The wide temporal and petrologic variations, as well as the fact that the ophiolites are younger going downward through a nappe pile, are common features among the circum-Pacific ophiolite belts. The time and space distribution of the Japanese ophiolites most closely resembles that in the Klamath Mountains of the western United States.

\section{Introduction}

Geologic, petrologic, geochemical, and geochronological studies, aided by the rapid development of the radiolarian biostratigraphy of the associated sediments, have revealed that the Japanese islands are composed of a pile of nappes (Ichikawa, 1990) in which older ophiolites are piled up on younger ophiolites. These ophiolites range from early Paleozoic to Tertiary in igneous age, and they generally become younger oceanward, although this trend often is complicated by the presence of tectonic outliers (klippes) of older rocks on the outer (oceanside) zones (Ishiwatari, 1991).

The multiple ophiolitic nappe pile in Japan shares features in common with analogous nappe piles that encircle the Pacific Ocean (for example, the Koryak Mountains, USSR; Alaska, USA; Klamath Mountains, USA; Chile; and eastern Australia). In addition, it is a typical segment of the circum-Pacific Phanerozoic multiple ophiolite belts with respect to its wide chronological range and to the regular time and space distribution of the ophiolites.

The 1992 International Geological Congress (IGC) in Kyoto will provide several field trips that will visit Japanese ophiolites (numbers A1, A2, C1 (Hokkaido), C10 (near Tokyo), C22 (near Kyoto), and A25 (southwestern Japan transect)). The IGC also will offer a symposium especially devoted to ophiolites (symposium I-3, number 26; number 38 also will deal with mantle peridotite). For participants from aboard, this paper presents a short review on the Japanese ophiolites in comparison with the other circum-Pacific ophiolites.

\section{Ophiolites in the Japanese islands}

\author{
Ophiolites in the Inner Zone of southwestern Japan
}

Early Paleozoic ophiolite nappes

The oldest ophiolite in southwestern Japan is the Oeyama ophiolite of Ordovician age (fig. 1). This ophiolite is composed of residual lherzolitic harzburgite, closely resembling abyssal peridotites, and minor mafic to ultramafic cumulates, but sheeted dikes and volcanic rocks are absent (Arai, 1980; Kurokawa, 1985). Potassium-argon (K-Ar) ages of hornblende in the layered gabbro are about $460 \mathrm{Ma}$ (Nishimura and Shibata, 1989). In the Hida Mountains of central Honshu, this ophiolite is associated with Silurian and Devonian sediments, which are a possible original cover, and it is overlain by the Hida nappes that are made of Paleozoic and Mesozoic continental crustal rocks. The Oeyama ophiolite is, in some places, underlain by high-pressure Omi metamorphic rocks of Carboniferous age (about $300 \mathrm{Ma}$ ) and by seamount-reef limestone complexes (Akiyoshi nappes) of late Paleozoic age. The Sekinomiya ultramafic body, the largest exposure $(20 \times 5 \mathrm{~km})$ of the Oeyama ophiolite, was thrust upon the mafic volcanic rocks of the Permian Yakuno ophiolite.

\section{Late Paleozoic ophiolite nappes}

The Permian Yakuno ophiolite and its sedimentary cover (Permian and Triassic) form a nappe called the Maizuru zone (Hayasaka, 1990). The outcrops of the Yakuno ophiolite mainly consist of basalt and gabbro without a sheeted dike complex and are thoroughly metamorphosed at temperatures that increase going downward through the ophiolite succession. The Moho part of this ophiolite that is exposed in the easternmost outcrops on the Sea of Japan coast (Oshima Peninsula) consists of layered metamorphic cumulates of spinel lherzolite and granulite-facies mafic rocks (plagioclaseorthopyroxene-calcic clinopyroxene-spinel). The highly aluminous nature of the pyroxene and the olivine-plagioclase reaction relationships in these rocks indicate a 15 - to $30-\mathrm{km}$-deep Moho at the time of subsolidus cooling (Ishiwatari, 1985a). The mantle part of this ophiolite includes layered wehrlite cumulates, massive dunite, and thick, moderately depleted, residual harzburgite (Ishiwatari, 1985b). Geochemical studies revealed that the Yakuno ophiolite is composed of two distinct segments, transitional mid-oceanic-ridge basalt (T-MORB) suites dominating the eastern outcrops and arc tholeiite suites dominating the western outcrops, which suggests that the origin of this ophiolite was in a Permian island arc-marginal basin system (Ishiwatari and others, 1990).

The Yakuno ophiolite is underlain by the Tamba nappes, which consist of Jurassic sandstone that includes blocks of chert, limestone, and pillow-lava bodies (seamount fragments) of late Paleozoic and early Mesozoic ages. The Tamba nappes appear on both sides (north 


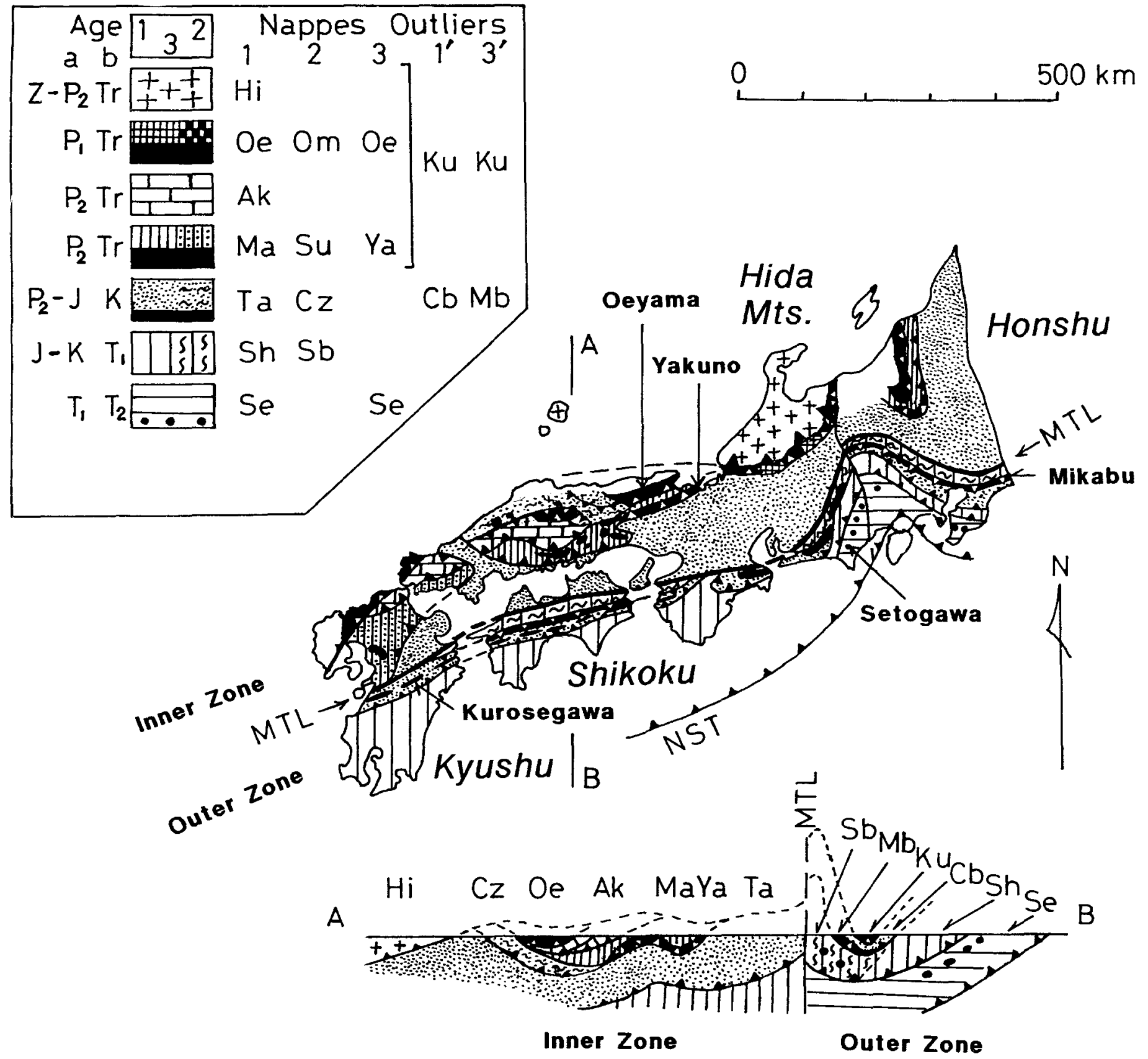

Figure 1. - Distribution and structural position of ophiolites (black areas and dots) in the nappe pile of southwestern Japan. The ophiolites generally form the basal part of a nappe group, whose names are given in the upper left of the block in the description (1), along with the names of the high-pressure metamorphic equivalents (2) and the ophiolitic basement (3). The nappe boundaries follow those of Ichikawa (1990), and the cross section follows that of Isozaki and others (1991), who interpreted the nappes of older rocks in the Outer Zone to be tectonic outliers of the Inner Zone. The age of the basement and preorogenic sediments is shown for each nappe group (a), as well as the age of the first postorogenic sediments or granite intrusions (b). Abbreviations of geologic ages: $Z$, Precambrian; P, Paleozoic; $P_{1}, P_{2}$, early or late Paleozoic; $T r$, Triassic; J, Jurassic; $K$, Cretaceous; $T_{1}, T_{2}$, Paleogene or Neo- gene of the Tertiary. Names of the nappes in alphabetical order: Ak, Akiyoshi; Cb, Chichibu; Cz, Chizu; Hi, Hida-Oki; Ku, Kurosegawa; Ma, Maizuru; Mb, Mikabu;Oe, Oeyama; Om, OmiRenge-Shitani; Sb, Sanbagawa; Se, Setogawa; Sh, Shimanto; Su, Suo; Ta, Tamba-Mino-Ashio-Ryoke; Ya, Yakuno. The Om, $\mathrm{Cz}$, and $\mathrm{Su}$ nappes consist of high-pressure metamorphic rocks that previously were referred to collectively as the "Sangun belt." The names of major ophiolitic bodies are shown on the map. MTL is the Median Tectonic Line, which separates the Inner Zone from the Outer Zone. The sawtoothed lines represent thrust faults bounding nappes, thick lines stand for high-angle faults, and dashed lines suggest their possible extensions. The current subduction occurs along the Nankai-Suruga-Sagami Trough (NST). 
and south) of the Paleozoic ophiolite nappes (Oeyama and Yakuno), which may be huge remnant klippes occupying the axial zone of a large synform (fig. 1).

\section{Ophiolites in the Outer Zone of southwestern Japan}

The Kurosegawa serpentine mélange (Maruyama and others, 1984) may occupy the highest structural position in the nappe pile of the Outer Zone (Isozaki and others. 1991). The mélange includes preSilurian granites and garnet gneisses. Silurian and Devonian limestone, upper Paleozoic glaucophane schists, upper Paleozoic reef limestone, and Triassic to Jurassic shallow-water clastic material. The peridotite blocks in the serpentinite (Yokoyama, 1987) resemble those of the Oeyama ophiolite with respect to primary mineral chemistry. This mélange may be a fragmental mixture of the Paleozoic nappes of the Inner Zone (Hida nappes, Oeyama ophiolite, Akiyoshi nappes, Maizuru nappe(?), and their postorogenic Mesozoic cover rocks).

The Chichibu nappes underlying the Kurosegawa nappes are almost identical in lithostratigraphy to the Tamba nappes. However, the Chichibu nappes include the Mikabu ophiolite mélange (Iwasaki, 1984 ) in their basal part. which is not exposed in the Inner Zone. The mélange includes meter to kilometer-sized blocks of pillow lavas, diabase dikes, gabbros, and cumulus ultramafic rocks that are buried in a matrix of mafic clastic rocks. Residual peridotite has never been encountered in this mélange. The Late Jurassic Chichibu nappes and the Mikabu mélange may be exposed along the axis of a synform between the Cretaceous Shimanto nappes on the south and the Sanbagawa nappes on the north. which consist of Cretaceous highpressure metamorphic rocks.

In the Sanbagawa nappes, we find a dunite-eclogite body and some metagabbro bodies that locally have a primary granulite-facies mineralogy and a contact-thermal effect on the surrounding highpressure metamorphic rocks, as well as many other small serpentinite bodies (Kunugiza and others, 1986). These bodies may be either ophiolite fragments that were metamorphosed at high pressures or hot intrusions that were emplaced in the deep part of a subduction zone.

The Shimanto nappes include many pillow-lava bodies of MORB chemistry that are found among turbidites. The turbidites are cut sometimes by Miocene gabbro dikes of MORB chemistry. This relationship suggests the presence of ongoing MORB magmatism in a forearc environment (Miyake, 1985).

The Tertiary Setogawa nappes underlying the Shimanto nappes formed in front of the Izu-Mariana arc, which has been colliding with Japan since Miocene time. These nappes include ophiolitic olistostromes that contain a wide variety of rocks such as titanium-rich tholeiite and picrite, gabbro, amphibolite, plagioclase lherzolite, and highly magnesian dunite (Arai, 1991). These ophiolitic rocks are of Oligocene to Miocene age and are some of the youngest ophiolitic rocks on land. We should note that a Tertiary ophiolite assemblage also was obtained from submarine seamounts in the forearc region of the Izu-Bonin-Mariana arc (Ishii, 1985).

\section{Ophiolite nappes and mélanges in northeastern Japan}

\section{Early Paleozoic ophiolites}

The Ordovician ophiolites in the Kitakami Mountains of northern Honshu are dominated by ultramafic rocks, which are composed mainly of residual harzburgite and minor cumulus rocks. The harzburgite commonly contains hornblende and phlogopite, and it may represent a fragment of hydrous upper mantle beneath an Ordovician island arc (Ozawa, 1988). Tazawa (1988) believes that the South Kitakami nappe, which is composed of the basal MiyamoriHayachine ophiolite, its sedimentary cover deposited from the Silurian through the Jurassic, and Paleozoic high-pressure metamorphic rocks of the Motai melange, was thrust over the Jurassic accretionary complex of North Kitakami (fig. 2). This relationship resembles that between the Oeyama ophiolite, Omi mélange, and Tamba nappes in southwestern Japan, although the Permian ophiolite between them is absent here.

\section{Late Jurassic ophiolites}

In central Hokkaido, a conspicuous westward-thrusting structure is due to the Tertiary Hidaka orogeny, which was caused by the collision of the Kurile arc. However, the Mesozoic accretionary complexes occupying most of the island have a primary structure that is dominated by eastward thrusting, although this is complicated by Tertiary backthrusting that shows significant strike-slip movement (Jolivet and Miyashita, 1985). The Horokanai ophiolite (Ishizuka, 1985) has a stratified succession that is made up of highly depleted, calcic clinopyroxene-free harzburgite, dunite-orthopyroxenite cumulates, layered gabbro, massive gabbro, and pillow basalt in ascending order, but a sheeted dike complex is absent. The pillow basalt is of MORB chemistry but may not be comagmatic with the underlying, highly depleted cumulus and residual peridotites. The pillow basalt is capped by radiolarite of Late Jurassic (Tithonian) age, which is, in turn, covered by thick clastic sediments of Cretaceous age. The Horokanai ophiolite and its equivalents may form the basal part of the Early Cretaceous accretionary complex and tectonically may underlie the Jurassic accretionary complex occupying the North Kitakami Mountains and southwestern Hokkaido. The Horokanai ophiolite was thrust over the Kamuikotan serpentine mélange, which was affected by Cretaceous high-pressure metamorphism (Maekawa, 1989).

\section{Cretaceous ophiolites}

The Cretaceous Hidaka Group contains some fragmental ophiolitic bodies of relatively differentiated MORB chemistry (Miyashita and Yoshida, 1988). Some of these bodies formed in place among the surrounding sediments in a forearc-basin environment and resemble the MORB magmatism in the Shimanto nappes of southwestern Japan. The Poroshiri ophiolite (Miyashita and Yoshida, 1988) on the western edge of the Hidaka zone includes a thoroughly metamorphosed volcanic sequence and well-layered mafic cumulates, which are partly amphibolitized but mostly preserve an igneous mineralogy. A sheeted dike complex is absent. The Horoman plagioclase lherzolite body in the southernmost part of the Hidaka Mountains may represent a lower crust to mantle section of the Cretaceous oceanic lithosphere. Takahashi (1991) found exotic blocks of highly depleted dunite-harzburgite, a few hundred meters in size, in the plagioclaserich lherzolite sequence. The blocks may be fragments of the preexisting depleted mantle (possibly of the Jurassic Horokanai ophiolite) that was captured in the Cretaceous mantle diapir (Horoman body). The partial melting and segregation processes have been well studied (Obata and Nagahara, 1987) in this lherzolite body, the freshest and most attractive peridotite body in Japan.

\section{Possible tectonic outlier}

The Tokoro zone in eastern Hokkaido is composed of pillow-lava bodies and associated sediments of Late Jurassic age that are older than the surrounding Cretaceous to Paleogene sediments. The mafic rocks underwent high-pressure metamorphism that was analogous to that of the Kamuikotan zone to the west (Sakakibara, 1986). The 

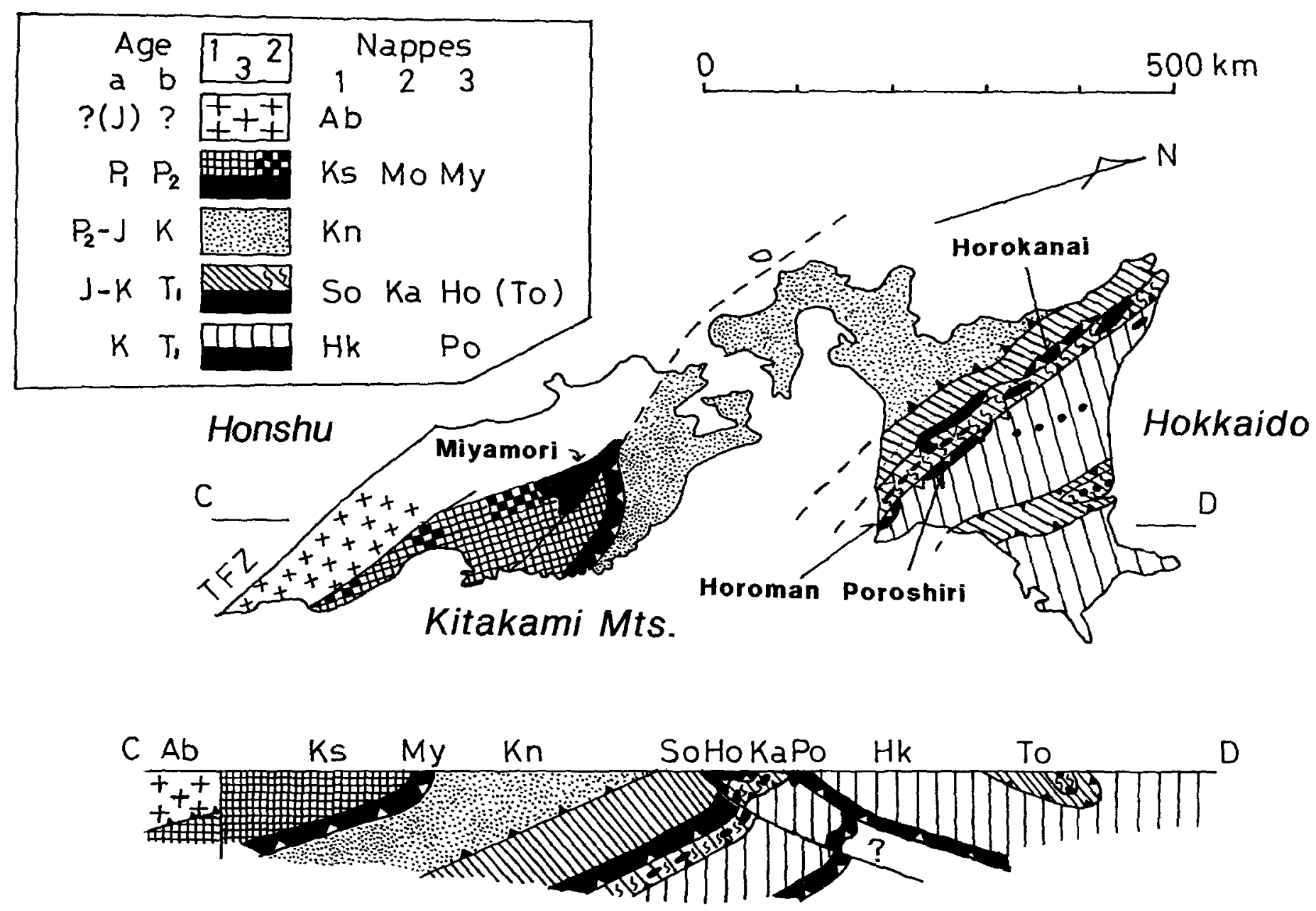

Figure 2.-Distribution and structural position of ophiolites (black areas and dots) in the nappe pile of northeastern Japan. The pre-Tertiary nappe pile formed by eastward thrusting and was deformed by the Miocene westward backthrusting in central Hokkaido. The cross section is my speculation that was stimulated by Tazawa (1988) and Miyashita and Yoshida (1988). Symbols and abbreviations are the same as in figure 1. Names of the nappes and

Tokoro zone is known to occupy the axial part of a large synform, and it may also be a tectonic outlier (klippe) of the Kamuikotan zone.

\section{Comparison with the other circum-Pacific ophiolite belts}

The fact that the ophiolites are younger going downward through the nappe pile is a common feature of the circum-Pacific orogenic belts. In the accretionary complexes of the Koryak Mountains along the Bering Sea coast (Palandzhjan, 1986; Stavsky and others, 1990), the oldest ophiolite occupying the highest position in the nappe pile is Ordovician to Devonian in age (Ust'Belaya ophiolite zone). The late Paleozoic and Jurassic ophiolites occur as fragmental klippes and mélanges in the underlying nappes, which were emplaced in Cretaceous time. Some of these ophiolites bear eclogite, garnet lherzolite, terranes: Ab, Abukuma; Hk, Hidaka-Nemuro; Ho, Horokanai; Ka, Kamuikotan; Kn/Ks, North/South Kitakami; Mo, Motai; My, Miyamori; Po, Poroshiri; So, Sorachi-Yezo; To, Tokoro (a possible tectonic outlier). The names of major ophiolitic bodies are given on the map. Northeastern and southwestern Japan are bounded by the Tanakura fault zone (TFZ).

and even diamond (Lavrova, 1980). An outer zone of ophiolitebearing Paleozoic formations (Ekonay zone) may be analogous to the Chichibu and Kurosegawa nappes in southwestern Japan. The Ekonay zone has been interpreted as a collided microcontinent. but the zone may be a remnant klippe of an older accretionary complex instead.

The ages of Alaskan ophiolites range from the late Paleozoic to the Jurassic. DeBari and Coleman (1989) reported that the Tonsina ophiolitic complex contains garnet granulite that was derived from the Moho, and they suggested that the complex represents the base of a thick island-arc crust.

In the Klamath Mountains, extending from northern Califomia into Oregon in the western United States (Irwin, 1977; Coleman, 1986), the Ordovician Trinity ophiolite is a huge plagioclase lherzolite body. It occupies the highest structural position in the nappe pile. which also includes Devonian blueschists, late Paleozoic to Early Jurassic ophiolites (for example, the Seiad and Preston Peak ophiolites), and the Late Jurassic Josephine ophiolite in descending order. 
This pre-Cretaceous nappe pile as a whole overlies the Cretaceous Franciscan mélange.

In Chile (Hervé and others, 1987), the Cordilleran orogen along the Pacific coast includes Ordovician ophiolitic rocks, a late Paleozoic subduction complex containing ophiolitic fragments, and Early Cretaceous marginal-basin ophiolites (for example, the Sarmiento complex).

In and around Australia, the oldest part of the accretionary complex is exposed in the Tasman belt, where a number of Cambrian and Ordovician ophiolites are incorporated among the accreted oceanic and forearc sediments of all Paleozoic times (Leitch and Scheibner. 1987). A well-developed Permian ophiolite is present in South Island, New Zealand. Younger Cretaceous ophiolites are found in other islands around Australia, such as New Caledonia and Papua New Guinea.

Proterozoic ophiolites have been reported from Pan-African orogenic belts (Pallister and others, 1987), and even Archean ophiolites are present in South Africa (de Wit and others, 1990) and Greenland (Maruyama and others, 1991). The apparent absence of such old ophiolites in the circum-Pacific belt may define the age of the Pacific Ocean itself.

\section{Conclusion}

The circum-Pacific accretionary complexes probably developed throughout the entire Phanerozoic and consisted of several roughly synchronous episodes of ophiolite formation and subsequent emplacement. Most of these ophiolites formed in island arc-related environments such as the forearc, intra-arc (volcanic front), and backarc (marginal sea) environments. The episodes of ophiolite generation (ophiolite pulses) took place in Ordovician, Permian, Jurassic, and Cretaceous time, which may be coeval to those that formed the Appalachian-Caledonian-Ural, Hercynian, and Alpine-Himalayan ophiolite belts in the continental hemisphere, respectively. The highly dismembered occurrence, a general absence of the sheeted dike complex, the intense metamorphism of the crustal mafic section, and the high-pressure (meta-) cumulates from a deep Moho may be significant features of circum-Pacific ophiolites ("Cordilleran-type" ophiolites of Coleman, 1986). However, their most important geotectonic feature is their temporal and spatial multiplicity, that is, the multiple superposition of ophiolite nappes of widely varying ages, in contrast to the single-age ophiolite belts found in the continental hemisphere. In this context, the Japanese islands are a typical segment of the circum-Pacific Phanerozoic multiple ophiolite belts.

\section{Acknowledgment}

I thank Dr. S.R. Wallis of Kyoto University for improving the English of this paper.

\section{References}

Arai, S., 1980, Dunite-harzburgite-chromitite complexes as refractory residue in the Sangun-Yamaguchi zone, western Japan: Journal of Petrology, v. 21, p. 141-165.

1991, The circum-lzu massif peridotite, central Japan, as back-arc mantle fragments of the Izu-Bonin arc system, in Peters, $T$., and others, eds., Ophiolite genesis and evolution of oceanic lithosphere (proceedings of the Oman 90 symposium): Dordrecht, Kluwer Academic Publishers, p. 807-822.
Coleman, R.G., 1986, Ophiolites and accretion of the North American Cordillera: Bulletin de la Société Géologique de France, 8th series, v. 2, p. $961-968$.

DeBari, S.M., and Coleman, R.G., 1989, Examination of the deep levels of an island arc: Evidence from the Tonsina ultramafic-mafic assemblage, Tonsina, Alaska: Journal of Geophysical Research, v. 94, p. 4373-4391.

Hayasaka, Y., 1990, Maizuru terrane, in Ichikawa, K., Mizutani, S., Hara, I., Hada, S., and Yao, A., eds., Pre-Cretaceous terranes of Japan: Osaka, Japan, Osaka City University, Publication of International Geological Correlation Programme Project 224, p. 81-95.

Hervé, F., Godoy, E., Parada, M.A., Ramos, V., Rapela, C., Mpodozis, C., and Davidson, J., 1987, A general view on the Chilean-Argentine Andes, with emphasis on their early history, in Monger, J.W.H., and Francheteau, J., eds., Circum-Pacific orogenic belts and evolution of the Pacific Ocean basin: American Geophysical Union and Geological Society of America, Geodynamics Series, v. 18, p. 97-113.

Ichikawa, K., 1990, Pre-Cretaceous terranes of Japan, in Ichikawa, K., Mizutani, S., Hara, I., Hada, S., and Yao, A., eds., Pre-Cretaceous terranes of Japan: Osaka, Japan, Osaka City University, Publication of International Geological Correlation Programme Project 224, p. 1-12.

Irwin, W.P., 1977, Ophiolitic terranes of California, Oregon, and Nevada, in Coleman, R.G., and Irwin, W.P., eds., North American ophiolites: Oregon Department of Geology and Mineral Industries, Bulletin 95, p. $75-92$.

Ishii, T., 1985, Dredged samples from the Ogasawara fore-arc seamount or "Ogasaware Paleoland": A "fore-arc ophiolite," in Nasu, N., and others, eds., Formation of active ocean margins: Tokyo, Terra Scientific Publishing Company, p. 307-342.

Ishiwatari, A., 1985a, Granulite-facies metacumulates of the Yakuno ophiolite, Japan: Evidence for unusually thick oceanic crust: Journal of Petrology, v. 26, p. $1-30$.

1985b, Igneous petrogenesis of the Yakuno ophiolite (Japan) in the context of the diversity of ophiolites: Contributions to Mineralogy and Petrology, v. 89, p. 155-167.

1991, Time-space distribution and petrologic diversity of Japanese ophiolites, in Peters, T., and others, eds., Ophiolite genesis and evolution of the oceanic lithosphere (proceedings of the Oman 90 symposium): Dordrecht, Kluwer Academic Publishers, p. 731-751.

Ishiwatari, A., Ikeda, Y., and Koide, Y., 1990, The Yakuno ophiolite, Japan: Fragments of Permian island arc and marginal basin crust with a hot spot, in Malpas, J., and others, eds., Ophiolites: Oceanic crustal analogues (proceedings of the Troodos 87 symposium): Cyprus, Geological Survey Department, p. 497-506.

Ishizuka, H., 1985, Prograde metamorphism of the Horokanai ophiolite in the Kamuikotan zone, Hokkaido, Japan: Journal of Petrology, v. 26, p. $391-417$.

Isozaki, Y., Maruyama, S., and Itaya, T., 1991, Structure of the Southwest Japan Cordillera [abstract]: Geological Society of Japan, Annual Meeting, 98th, Matsuyama, 1991, p. 14-15. [In Japanese.]

Iwasaki, M., 1984, Sequence of igneous events and ocean-floor metamorphism in the greenstone (ophiolitic detritus deposit) from Eastern Shikoku, Japan: Ofioliti, v. 9, p. 443-462.

Jolivet, L., and Miyashita, S., 1985, The Hidaka shear zone (Hokkaido, Japan): Genesis during a right-lateral strike-slip movement: Tectonics, v. 4 , p. $289-302$.

Kunugiza, K., Takasu, A., and Banno, S., 1986, The origin and metamorphic history of the ultramafic and metagabbro bodies in the Sanbagawa metamorphic belt, in Evans, B.W., and Brown, E.H., Blueschists and eclogites: Geological Society of America Memoir 164, p. $375-385$.

Kurokawa, K., 1985, Petrology of the Oeyama ophiolitic complex in the Inner Zone of Southwest Japan: Science Reports of Niigata University, series E, Geology and Mineralogy, no. 6, p. 37-113.

Lavrova, L.D., 1980, Genesis of ultramafic rocks of the Maynits tectonic zone, Koryak Mountains: Doklady Akademii Nauk SSSR, v. 253, p. 1197-1200. [In Russian, English translation published in 1982 in Doklady Earth Science Sections, v. 253, p. 173-176.]

Leitch, E.C., and Scheibner, E., 1987, Stratotectonic terranes of the eastern Australian Tasmanides, in Leitch, E.C., and Scheibner, E., eds., Terrane accretion and orogenic belts: American Geophysical Union and Geological Society of America, Geodynamics Series, v. 19, p. 1-19. 
Maekawa, H., 1989. Two modes of mixing of Biei ophiolitic mélange. Kamuikotan blueschist belt, Japan: Journal of Geology, v. 97. p. $93-108$

Maruyama, S., Banno, S., Matsuda, T., and Nakajima, T., 1984. Kurosegawa zone and its bearing on the development of the Japanese islands: Tectonophysics, v. 110, p. 47-60.

Maruyama, S., Masuda, T., Nohda, S., Hagiya, H., Shibata, T., Otofuji, Y., Miki, M., and Appel, P., 1991, The oldest accretionary complex in the world: The geology of the Isua region, Greenland [abstract]: Geological Society of Japan, Annual Meeting, 98th, Matsuyama, 1991, p. 118. [In Japanese.]

Miyake, Y., 1985, MORB-like tholeiites formed within the Miocene forearc basin, Southwest Japan: Lithos, v. 18, p. 23-34.

Miyashita, S., and Yoshida, A., 1988, Pre-Cretaceous and Cretaceous ophiolites in Hokkaido, Japan: Bulletin de la Société Géologique de France, 8 th series, v. 4 , p. $251-260$.

Nishimura, Y., and Shibata, K., 1989, Modes of occurrence and K-Ar ages of metagabbroic rocks in the "Sangun metamorphic belt," Southwest Japan, in Nishimura, Y., Hashimoto, M., Hara, I., and Watanabe, T., High-pressure metamorphic belts and tectonics of the Inner Zone of southwestern Japan: Memoirs of the Geological Society of Japan, no. 33, p. 343-357. [In Japanese, English abstract.]

Obata, M., and Nagahara, N., 1987, Layering of alpine-type peridotite and the segregation of partial melt in the upper mantle: Journal of Geophysical Research, v. 92, p. 3467-3474.

Ozawa, K., 1988, Ultramafic tectonite of the Miyamori ophiolitic complex in the Kitakami Mountains, Northeast Japan: Hydrous upper mantle in an island arc: Contributions to Mineralogy and Petrology, v. 99. p. $159-175$

Palandzhjan, S.A., 1986, Ophiolite belts in the Koryak Upland, Northeast Asia: Tectonophysics, v. 127, p. 341-360.

Pallister, J.S., Stacey, J.S., Fischer, L.B., and Premo, W.R., 1987, Arabian Shield ophiolites and Late Proterozoic microplate accretion: Geology, v. 15 , p. $320-323$.

Sakakibara, M., 1986, A newly discovered high-pressure terrane in eastern Hokkaido, Japan: Journal of Metamorphic Geology, v. 4, p. 401-408.

Stavsky, A.P., Chekhovitch, V.D., Kononov, M.V., and Zonenshain, L.P., 1990, Plate tectonics and palinspastic reconstructions of the Anadyr-Koryak region, northeast USSR: Tectonics, v. 9, p. 81-101.
Takahashi, N., 1991, The evolutional history of the uppermost mantle of an arc system: Petrology of the Horoman massif, Japan, in Peters, T., and others, eds., Ophiolite genesis and evolution of the oceanic lithosphere (proceedings of Oman 90 symposium): Dordrecht, Kluwer Academic Publishers, p. 197-208.

Tazawa, J., 1988, Paleozoic-Mesozoic stratigraphy and tectonics of the Kitakami Mountains, Northeast Japan: Earth Science (Chikyu Kagaku), v. 42 , p. $165-178$. [In Japanese, English abstract.]

Wit, M.J. de, Tredoux, M., and Hart, R., 1990, 3.5 Ga oceanic-like lithosphere: Some chemical and geodynamic constraints on (Archean) earth models: EOS (American Geophysical Union Transactions), v. 71, p. $969-970$.

Yokoyama, K., 1987, Ultramafic rocks in Kurosegawa tectonic zone, Southwest Japan: Journal of the Japanese Association of Mineralogists, Petrologists and Economic Geologists, v. 82, p. 319-335

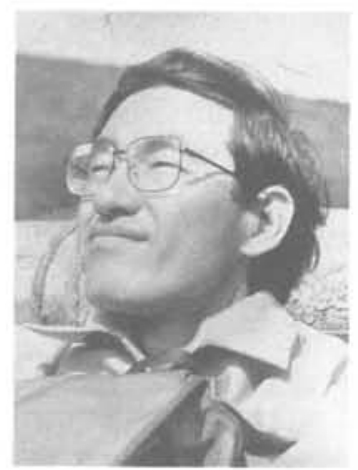

Dr. Akira Ishiwatari has been an Associate Professor of the Department of Earth Sciences, Faculty of Science, Kanazawa University since 1986. He grew up in Komae City (Tokyo) and came into contact with geology at Jindai High School. He graduated from Yokohama National University with a bachelor's degree, Kanazawa University with a master's degree, and the University of Tokyo with a doctoral degree for his thesis on the Yakuno ophiolite of Japan. He was a Maître Assistant Associé of Pierre et Marie Curie (Paris 6) University from 1982 through 1985. where he studied Alpine ophiolites. Photograph taken by A. Ushakov in the Koryak Mountains of the USSR in July 1990. 